\title{
Hubungan Terapi Komplementer dengan Psychological Well Being pada Pasien Penyakit Ginjal Kronis Stadium 5
}

\author{
Sri Elis Rohaeti ${ }^{1 *}$, Kusman Ibrahim ${ }^{2}$, Sri Hartati Pratiwi ${ }^{3}$ \\ ${ }^{1,2,3}$ Fakultas Keperawatan, Universitas Padjadjaran, Indonesia \\ *Alamat Korespondensi: UPI Kampus Sumedang, Jalan Mayor Abdurahman, Kotakaler, \\ Sumedang 45322 \\ Email: srielisrohaeti@gmail.com
}

Diterima: 30 Desember 2020 | Disetujui: 13 Juni 2021

\begin{abstract}
Abstrak
Latar Belakang dan Tujuan: Penyakit Ginjal Kronis stadium 5 dengan Dialisis (PGK5D) merupakan penyakit kronis yang memerlukan terapi pengganti seumur hidup sehingga pasien memerlukan perawatan paliatif untuk mengurangi gejala, memperhatikan aspek psikologis, spiritual, serta meningkatkan kualitas hidup. Terapi komplementer adalah metode yang digunakan untuk mengontrol gejala, berpengaruh kepada pengendalian perasaan, sikap serta emosi. Tujuan dari penelitian ini mengetahui hubungan penggunaan terapi komplementer dengan Psychological Well Being (PWB).

Metode: Desain menggunakan korelasi dengan pendekatan cross sectional. Sampel 97 responden, teknik Sampling Purposive, kriteria inklusi pasien menjalani hemodialisis lebih dari 3 bulan, pernah atau sedang menggunakan terapi komplementer. Menggunakan kuesioner Complementary Alternative Medicine yang disusun peneliti, validitas 0,482-0,884, reliabilitas 0,931 serta kuesioner PWB adaptasi skala Carol Ryff validitas 0,456-0,905, reliabilitas 0,975 .

Hasil: Terdapat hubungan yang signifikan antara penggunaan terapi komplementer dengan PWB $(r=0.418, p$ value $=0.000)$. Jenis terapi komplementer yang banyak digunakan adalah teknik pijat tradisional, dimensi keyakinan dan komunikasi memiliki rata-rata terendah dan dimensi PWB yang masih rendah yaitu otonomi, tujuan hidup dan penerimaan diri.

Simpulan dan Implikasi: Perawat dapat mengikuti pelatihan pijat refleksi untuk memberikan pendidikan kepada keluarga pasien dan caregiver, menyediakan terapi doa dan lantunan Al-Qur'an selama intradialitik.
\end{abstract}

Kata Kunci: Kesejahteraan Psikologis; Penyakit Ginjal Kronis Stadium 5; Terapi Komplementer

Sitasi: Rohaeti, S.E., Ibrahim, K., \& Pratiwi, S.H. (2021). Hubungan terapi komplementer dengan psychological well being pada pasien penyakit ginjal kronis stadium 5. The Indonesian Journal of Health Science. 13(1),12-24. DOI: 10.32528/ijhs.v13i1.4004

Copyright: (C) 2021 Rohaeti, et al. This is an open-access article distributed under the terms of the Creative Commons Attribution-NonCommercial 4.0 International License, which permits unrestricted use, distribution, and reproduction in any medium, provided the original author and source are credited.

Diterbitkan Oleh: Universitas Muhammadiyah Jember

ISSN (Print): 2087-5053

ISSN (Online): 2476-9614 


\begin{abstract}
Background and aim: Stage 5 Chronic Kidney Disease with Dialysis is an incurable chronic diseases, requiring lifelong replacement therapy so that patients need palliative care to reduce symptoms, pay attention psychological aspects, improve quality of life. Complementary therapy is a method that can be used to control symptoms, feelings, attitudes, emotions. The purpose was to find out the relationship between complementary therapy use and Psychological Well Being $(P W B)$.

Methods: Study design used correlation with a cross sectional approach. Samples were 97 taken by purposive sampling technique. The inclusion criteria are patients undergoing hemodialysis more than 3 months, have or are using complementary therapy. complementary alternative medicine questionnaires compiled by the researchers. The validity is 0.482-0.884, reliability 0.931, PWB questionnaire adaptation scale has a Carol Ryff validity of 0.456-0.905, reliability 0.975 .
\end{abstract}

Results: Pearson's correlation analysis showed that there is a significant correlation between complementary therapeutic use and PWB ( $r=0.418, p$ value $=0.000$ ). The type of complementary therapy widely used is a traditional massage technique. The dimensions of confidence and communication have the lowest average and PWB dimensions that are still low are autonomy, life goals, self-acceptance.

Conclusion: Nurses follow reflexology training to educate family support and Caregiver to do so, providing prayer therapy and reciting the Qur'an during the intradialytic.

Keywords: Complementary Therapy; Chronic Kidney Disease Stage 5; Psychological Well-Being.

\section{PENDAHULUAN}

Penyakit Ginjal Kronis Stadium 5 dengan Dialisis (PGK5D) telah menjadi penyakit yang mendunia dengan jumlah penderita yang terus bertambah, dengan perkembangan penyakit yang buruk dan pembiayaan tinggi. Menurut Perhimpunan Nefrologi Indonesia diperkirakan sekitar $12,5 \%$ dari populasi atau sebesar 25 juta penduduk Indonesia mempunyai fungsi ginjal yang menurun (Indonesian Renal Registry, 2014). Pembiayaan terbesar Badan Penyelenggara Jaminan Sosial (BPJS) kesehatan ditempati oleh perawatan penyakit jantung disusul oleh perawatan penyakit ginjal (Hasneli, 2017). Besarnya pembiayaan perawatan penyakit ginjal ini dikaitkan dengan mahalnya terapi pengganti fungsi ginjal.

Terapi pengganti ginjal yang banyak menjadi pilihan adalah hemodialisis (Indonesian Renal Registry, 2014). Hemodialisis adalah terapi sepanjang hidup yang sangat berarti dan kadang-kadang menimbulkan efek samping kepada pasien baik fisik maupun psikologis (Kimmel, 2001). Efek psikologis yang muncul berupa meningkatnya rasa cemas, kelelahan, menurunnya kualitas hidup, meningkatnya risiko bunuh diri, dari 200 pasien PGK5D 21,5\% mempunyai ide bunuh diri, 3,3\% berencana bunuh diri satu bulan sebelumnya, dan $3,5 \%$ berusaha bunuh 
diri sepanjang hidupnya (Chen ken Chih et al, 2010). Respon psikologis ini dapat mempengaruhi kesejahteraan psikologis pasien.

Kesejahteraan psikologis atau Psychological Well Being (PWB) kondisi keadaan jiwa yang sehat, sejauhmana individu menjalani kehidupannya dengan penuh makna, mempunyai tujuan hidup, bermanfaat bagi sesama dan dirinya sendiri. Terdiri dari enam dimensi, otonomi, penguasaan lingkungan, pertumbuhan pribadi, hubungan positif dengan orang lain, tujuan dalam hidup dan penerimaan diri (Ryff, 2014). Penelitian juga dilakukan pada 172 pasien PGK5D dengan hasil pasien memiliki kepuasan hidup yang lebih rendah, turunnya prestasi hidup dan memiliki hubungan yang lebih rendah dengan orang lain dibandingkan dengan populasi umum (Bennett, 2015).

Penatalaksanaan pada pasien PGK5D meliputi penatalaksanaan komplementer, penatalaksanaan konservatif dengan obat dan terapi pengganti ginjal. Hemodialisis merupakan perawatan yang sulit karena memerlukan kehadiran di pusat perawatan, menghasilkan banyak batasan seperti dalam diet dan penggunaan obat-obatan medis, serta mengarah pada perubahan gaya hidup. Pasien mencari metode pengobatan komplementer bersama dengan perawatan medis untuk menghindari kondisi tersebut, meningkatkan kualitas hidup, memiliki kontrol dan tanggung jawab yang lebih besar untuk perawatan (Ceyhan \& Goris, 2017). Kesadaran tentang risiko interaksi penggunaan beberapa jenis terapi komplementer sangat rendah pada pasien dialisis sekitar 39\% (Nowack et al., 2009). Jenis komplementer yang sering digunakan oleh pasien PGK5D adalah produk biologi berupa herbal dan produk alami, serta praktik pikiran tubuh seperti relaksasi, meditasi, nafas dalam, dan terapi spiritual (Osman et al., 2015).

PGK5D termasuk kedalam penyakit kronis yang tidak dapat disembuhkan, sehingga pasien memerlukan perawatan paliatif yang bertujuan untuk mengurangi gejala yang mengganggu dengan memperhatikan aspek psikologis dan spiritual pasien maupun keluarga, dan meningkatkan kualitas hidup dimana kualitas hidup ini erat kaitannya dengan perasaan, emosi dan kesejahteraan psikologis. Penggunaan terapi komplementer mempengaruhi perasaan, sikap dan emosi. Kondisi yang tenang ini akan menstimulasi tubuh untuk mengeluarkan hormon seperti endorphin yang dapat menurunkan kecemasan. Juga hormon yang seperti adrenalin, nor adrenalin dan kortisol dihambat, sehingga munculnya keseimbangan dalam tubuh dan organ tubuh dapat berfungsi dengan baik (Artana, 2017).

Beberapa jenis terapi komplementer belum teruji manfaatnya pada populasi PGK5D, dimana beberapa produk herbal ini mengandung banyak senyawa aktif farmakologi, ketika digunakan oleh orang-orang dengan penyakit ginjal, mungkin berbahaya. Namun saat ini sudah ada beberapa terapi komplementer yang teruji manfaat dan keamanannya bahkan penggunaanya mengalami peningkatan dari tahun 2002 sampai 2007 di Amerika Serikat seperti intervensi nafas dalam, meditasi, pijat dan yoga (NCCAM, 2008).

Perawat memiliki peranan penting dalam penggunaan terapi komplementer diantaranya sebagai tempat konsul dan tempat berdiskusi 
dengan pasien ketika pasien atau keluarga memerlukan acuan sebelum memutuskan untuk menggunakan terapi komplementer, memberikan penjelasan jenis komplementer yang aman dan dapat digunakan oleh pasien PGK5D (Widyatuti, 2008). Perawat memiliki kesempatan untuk berkomunikasi dengan pasien dan petugas kesehatan lainnya lebih banyak sehingga dapat berdiskusi tentang penggunaan terapi komplementer dengan petugas kesehatan lainnya, perawat memiliki tugas dalam memberikan pelayanan kepada pasien misalnya dalam praktik pelayanan kesehatan yang melakukan integrasi terapi komplementer (Snyder \& Lindquist, 2018).

Selain penggunaan terapi komplementer perawat juga berperan dalam setiap fase adaptasi psikologis pasien PGK5D mulai dari fase akut sampai fase dimana pasien dapat beradaptasi dalam jangka waktu yang lama dengan kondisi dialisis. Selama peneliti melakukan telaah literatur ada beberapa penelitian survey yang telah dilakukan di luar negeri tentang penggunaan terapi komplementer pada pasien hemodialisis dan penelitian tentang Psychological Well Being, namun belum banyak yang menghubungkan penggunaan terapi komplementer dengan PWB pada pasien PGK5D di Indonesia, sehingga penulis merasa perlu untuk melakukan penelitian tentang Hubungan Penggunaan Terapi Komplementer dengan Psychological Well Being pada Pasien Penyakit Ginjal Kronis Stadium 5 yang Menjalani Hemodialisis. Dengan demikian maka tujuan dari penelitian ini yaitu mengetahui hubungan penggunaan terapi komplementer dengan Psychological Well Being (PWB).

\section{METODE PENELITIAN}

Penelitian ini menggunakan desain korelasi dengan pendekatan cross sectional. Populasi adalah seluruh pasien dengan diagnosa PGK stadium 5 yang menjalani hemodialisis rutin 2 kali dalam satu minggu di RSUD Kabupaten Sumedang. Besar sampel dihitung menggunakan Tabel power analysis, effect size yang digunakan sebesar 0.30 dengan besar sampel 88 responden (Polit \& Beck, 2014). Ditambah $10 \%$ dengan maksud untuk mengatasi responden yang mengalami drop out sehingga jumlah sampel yang digunakan adalah sebanyak 97 responden. Peneliti melakukan pemilihan responden yang sesuai dengan kriteria inklusi dengan teknik Non random sampling purposive. Kriteria inklusi: Pasien yang menjalani hemodialisis lebih dari 3 bulan, Pasien yang pernah atau sedang menggunakan terapi komplementer, Pasien dapat berkomunikasi secara verbal dan Compos Mentis atau kesadaran penuh, Bersedia menjadi responden. Dari populasi 204 responden yang memenuhi kriteria inklusi sebanyak 104 responden, 7 responden tidak menyelesaikan penelitian dikarenakan tidak mengembalikan kuesioner dan tidak hadir pada pertemuan kedua, sehingga total sampel yang digunakan adalah 97 responden.

Variabel terdiri dari dua, variabel pertama adalah penggunaan terapi komplementer. Variabel kedua adalah Psychological Well Being. Penelitian ini dilakukan di Unit Hemodialisis RSUD Sumedang, dari 7 April sampai dengan 30 April 2020. Instrumen terdiri dari dua yaitu instrumen yang menggali penggunaan terapi komplementer yaitu kuesioner Complementary Alternative Medicine (CAM) dan instrumen yang menggali 
kesejahteraan psikologis yaitu kuesioner Psychological Well Being (PWB) adaptasi skala Carol Ryff. Dilakukan uji validitas konstruk kuesioner CAM $r$ hasil sebesar 0,4820,884 dengan tingkat signifikasi dua arah sebesar 5\% ( $\mathrm{r}$ tabel 0,443). Validitas PWB $\mathrm{r}$ hasil 0,456-0,905 dengan tingkat signifikasi dua arah sebesar 5\% (r tabel 0,443). Instrumen CAM memiliki nilai reliabilitas 0,931 dan instrumen PWB memiliki nilai reliabilitas 0,975 .

Pengambilan data telah mendapat izin penelitian dari RSUD Sumedang, izin uji validitas RSU Pakuwon dan mendapat izin etik dari Komisi Etik penelitian Universitas padjadjaran Bandung, tanggal 6 April 2020 nomer 382/UN6.KEP/EC/2020. Penelitian dilakukan dengan menggunakan kuesioner langsung dibagikan kepada responden namun dilakukan dengan tetap memperhatikan protokol kesehatan pencegahan Covid 19 dimana responden dan peneliti menggunakan APD, tetap menjaga jarak, kontak minimal, mencuci tangan sebelum dan setelah menyentuh kuesioner.

Analisis data univariat karakteristik responden dan jenis terapi komplementer disajikan dalam tabel distribusi frekuensi, penggunaan terapi komplementer dan Psychological Well Being disajikan dalam tabel tendensi sentral. Analisis bivariat, data variabel total penggunaan terapi komplementer dan PWB berdistribusi normal maka dianalisis menggunakan uji korelasi Pearson Product Moment, data dimensi penggunaan terapi komplementer dan PWB tidak berdistribusi normal maka diuji menggunakan uji korelasi Spearman Rank.

\section{HASIL}

Karakteristik responden dapat dilihat pada tabel 1 berdasarkan usia berada pada rentang usia dewasa pertengahan sebesar (67\%) dengan jenis kelamin terbanyak adalah perempuan (74,2\%). Tingkat pendidikan responden (33\%) adalah SLTA dengan sekitar (64,9\%) responden tidak bekerja. Berdasarkan status pernikahan $(90,7 \%)$ berstatus menikah dan selama proses hemodialisis sebagian besar responden diantar oleh keluarga sebanyak $(81,4 \%)$, dilihat dari aspek religiusitas $(74,2 \%)$ responden menyatakan religius dan (99\%) berasal dari suku Sunda.

Hasil penelitian jenis terapi komplementer yang digunakan responden dapat dilihat pada tabel 2 adalah metode manipulasi tubuh $(37,1 \%)$ dengan teknik pijat. Untuk penggunaan metode herbal alami dan suplemen penggunaan jamu gendong menempati urutan pertama sebesar $(9,3 \%)$ dan untuk metode pikiran tubuh mengunakan terapi air doa menempati urutan pertama sebesar (10,3\%). Beberapa responden juga menggunakan 2 jenis terapi seperti herbal alami dan teknik manipulasi tubuh serta teknik manipulasi tubuh dan teknik pikiran tubuh sebesar $(13,4 \%)$.

Tabel 3 menunjukan penjabaran dari jenis terapi komplementer berdasarkan kegunaan sebagian besar $(44,3 \%)$ digunakan untuk mengatasi keluhan pegal dan kelelahan, $(20,6 \%)$ untuk meningkatkan stamina. Hampir seluruhnya $(80,4 \%)$ responden mendapatkan terapi komplementer dari orang lain, $(51,5 \%)$ diantara responden adalah pengguna terapi komplementer sebelum tahu dan dinyatakan sakit ginjal dengan (44, 3\%) 
menggunakannya sebelum tahu sakit ginjal dengan frekuensi 1 minggu sekali atau lebih, $(62,9 \%)$ beranggapan tidak ada kaitan antara riwayat penggunaan terapi komplementer sebelum sakit ginjal dengan penyakit ginjalnya sekarang.

Hasil penelitian tentang penggunaan terapi komplementer dapat dilihat pada tabel 4 dimana total mean keempat dimensi adalah 38,42 $(\mathrm{SD}=9,589)$. Dua diantaranya memiliki nilai mean yang rendah yaitu dimensi keyakinan 5,71 $(\mathrm{SD}=1,98)$ dan dimensi komunikasi $6,19 \quad(\mathrm{SD}=2,82)$. Total rata-rata kesejahteraan psikologis adalah 180,77 $(\mathrm{SD}=18,72)$, terdapat tiga dimensi memiliki rata-rata terendah yaitu pada dimensi otonomi 27,59 $(\mathrm{SD}=4,50)$, dimensi tujuan hidup 29,03 ( $\mathrm{SD}=4,63)$, dan dimensi penerimaan diri 29,79 $(\mathrm{SD}=5,03)$.

Berdasarkan hasil pengujian korelasi Pearson menunjukkan bahwa penggunaan terapi komplementer dan Psychological Well Being (PWB) memiliki arah hubungan yang positif 0.418 dengan p-value 0.000 . Hal ini mengartikan bahwa ketika ada peningkatan penggunaan terapi komplementer maka Psychological Well Being (PWB) akan meningkat dengan peningkatan yang signifikan $(\mathrm{p}<0,05)$ dengan kekuatan hubungan yang sedang.

Tabel 1: Karakteristik Responden ( $\mathrm{n}=97)$

\begin{tabular}{|c|c|c|}
\hline Karakteristik & Frekuensi & Persentase \\
\hline \multicolumn{3}{|l|}{ Usia } \\
\hline 21-40 tahun (dewasa muda) & 15 & 15,5 \\
\hline 41-60 tahun (dewasa pertengahan) & 65 & 67 \\
\hline$>60$ tahun (dewasa akhir) & 17 & 17,5 \\
\hline \multicolumn{3}{|l|}{ Jenis kelamin } \\
\hline Laki-laki & 25 & 25,8 \\
\hline Perempuan & 72 & 74,2 \\
\hline \multicolumn{3}{|l|}{ Pendidikan } \\
\hline Tidak tamat SD atau SD & 29 & 29,9 \\
\hline SLTP & 29 & 29,9 \\
\hline SLTA & 32 & 33 \\
\hline D3, S1, S2, S3 & 7 & 7,2 \\
\hline \multicolumn{3}{|l|}{ Pekerjaan } \\
\hline Bekerja & 34 & 35,1 \\
\hline Tidak Bekerja & 63 & 64,9 \\
\hline \multicolumn{3}{|l|}{ Status pernikahan } \\
\hline Menikah & 88 & 90,7 \\
\hline Belum menikah/janda/duda & 9 & 9,3 \\
\hline \multicolumn{3}{|l|}{ Pengantar hemodialisis } \\
\hline Keluarga/teman & 79 & 81,4 \\
\hline Datang sendiri & 18 & 18,6 \\
\hline \multicolumn{3}{|l|}{ Religiusitas } \\
\hline $\mathrm{Ya}$ & 72 & 74,2 \\
\hline Tidak & 25 & 25,8 \\
\hline \multicolumn{3}{|l|}{ Suku bangsa } \\
\hline Sunda & 96 & 99 \\
\hline Non sunda & 1 & 1 \\
\hline
\end{tabular}


Tabel 2: Distribusi responden berdasarkan jenis terapi komplementer $(\mathrm{n}=97)$

\begin{tabular}{|c|c|c|c|}
\hline Jenis Penggunaan CAM & Nama Jenis CAM & Frekuensi & Persentase \\
\hline \multirow{11}{*}{$\begin{array}{l}\text { Herbal alami dan } \\
\text { suplemen }\end{array}$} & & 31 & 32,0 \\
\hline & Kunyit & 4 & 4,1 \\
\hline & Madu & 8 & 8,2 \\
\hline & Jamu gendong & 9 & 9,3 \\
\hline & Seledri & 1 & 1,0 \\
\hline & Jahe & 2 & 2,1 \\
\hline & Daun salam & 1 & 1,0 \\
\hline & Bawang putih & 1 & 1,0 \\
\hline & Vitamin & 3 & 3,1 \\
\hline & Kunyit madu & 1 & 1,0 \\
\hline & Jahe kunyit sereh & 1 & 1,0 \\
\hline Teknik manipulasi tubuh & Pijat & 36 & 37,1 \\
\hline \multirow[t]{4}{*}{ Teknik pikiran tubuh } & & 17 & 17,5 \\
\hline & Terapi air doa & 10 & 10,3 \\
\hline & Doa & 5 & 5,2 \\
\hline & Ruqiah & 2 & 2,1 \\
\hline Herbal alami & & 3 & 3,1 \\
\hline \multirow[t]{3}{*}{ manipulasi tubuh } & Jahe, Pijat & 1 & 1,0 \\
\hline & Jamu, pijat & 1 & 1,0 \\
\hline & Jahe kunyit madu, pijat & 1 & 1,0 \\
\hline Manipulasi tubuh & & 10 & 10,3 \\
\hline \multirow[t]{2}{*}{ teknik pikiran tubuh } & Pijat, terapi air doa & 4 & 4,1 \\
\hline & Pijat, doa & 6 & 6,2 \\
\hline
\end{tabular}

Tabel 3: Kegunaan terapi komplementer, cara mendapatkan, riwayat penggunaan sebelum Penyakit Ginjal Kronis ( $\mathrm{n}=97$ )

\begin{tabular}{|c|c|c|}
\hline Penggunaan komplementer & Frekuensi & Persentase \\
\hline \multicolumn{3}{|l|}{ Kegunaan } \\
\hline Pegal/lelah & 43 & 44,3 \\
\hline Mual & 7 & 7,2 \\
\hline Penurun tekanan darah & 3 & 3,1 \\
\hline Stamina & 20 & 20,6 \\
\hline Ketenangan kenyamanan & 12 & 12,4 \\
\hline Kesembuhan sakit ginjal & 12 & 12,4 \\
\hline \multicolumn{3}{|l|}{ Cara Mendapatkan } \\
\hline Didapat dari orang lain & 78 & 80,4 \\
\hline Membuat sendiri & 19 & 19,6 \\
\hline \multicolumn{3}{|l|}{ Penggunaan sebelum PGK } \\
\hline Pengguna sebelum PGK & 50 & 51,5 \\
\hline Bukan pengguna sebelum PGK & 47 & 48,5 \\
\hline \multicolumn{3}{|l|}{ Frekuensi Penggunaan sebelum PGK } \\
\hline $\begin{array}{l}\text { Tidak pernah menggunakan sebelum } \\
\text { PGK }\end{array}$ & 47 & 48,5 \\
\hline Menggunakan 1 bulan sekali & 7 & 7,2 \\
\hline Menggunakan 1 minggu sekali atau lebih & 43 & 44,3 \\
\hline \multicolumn{3}{|l|}{ Persepsi kaitan terapi komplementer dengan } \\
\hline PGK & & \\
\hline Ada kaitan penggunaan & 36 & 37,1 \\
\hline $\begin{array}{l}\text { komplementer dengan PGK } \\
\text { Tidak ada kaitan penggunaan terapi } \\
\text { komplementer dengan PGK }\end{array}$ & 61 & 62,9 \\
\hline
\end{tabular}


Tabel 4: Distribusi responden berdasarkan penggunaan terapi komplementer dan dimensi penggunaan $(\mathrm{n}=97)$

\begin{tabular}{|c|c|c|c|c|}
\hline Variabel & Mean & SD & Min-Max & $95 \%$ CI \\
\hline $\begin{array}{l}\text { Total penggunaan terapi } \\
\text { komplementer }\end{array}$ & 38,42 & 9,58 & $18-59$ & $36,49-40,36$ \\
\hline Frekuensi & 14,14 & 4,28 & $5-23$ & $13,28-15,01$ \\
\hline Keyakinan & 5,71 & 1,98 & $2-10$ & $5,31-6,11$ \\
\hline Dampak & 12,38 & 3,76 & $4-20$ & $11,62-13,14$ \\
\hline Komunikasi & 6,19 & 2,82 & $4-16$ & $5,62-6,75$ \\
\hline
\end{tabular}

Tabel 5: Kesejahteraan Psikologis Responden ( $\mathrm{n}=97)$

\begin{tabular}{lcccc}
\hline \multicolumn{1}{c}{ Variabel } & Mean & SD & Min-Max & $95 \%$ CI \\
\hline Total PWB & 180,77 & 18,72 & $127-218$ & $177,00-184,55$ \\
Otonomi & 27,59 & 4,50 & $18-40$ & $26,68-28,50$ \\
Penguasaan lingkungan & 31,27 & 5,02 & $19-42$ & $30,26-32,28$ \\
Pertumbuhan pribadi & 30,55 & 4,13 & $21-42$ & $29,71-31,38$ \\
Hubungan positif dengan & 32,55 & 4,93 & $18-42$ & $31,55-33,54$ \\
orang lain & & & & \\
Tujuan hidup & 29,03 & 4,63 & $18-41$ & $28,10-29,96$ \\
Penerimaan diri & 29,79 & 5,03 & $17-41$ & $28,78-30,81$ \\
\hline
\end{tabular}

Tabel 6: Uji Korelasi Penggunaan komplementer dengan PWB ( $\mathrm{n}=97)$

\begin{tabular}{|c|c|c|c|c|c|}
\hline \multirow[b]{2}{*}{ PWB } & \multicolumn{5}{|c|}{ Penggunaan terapi komplementer } \\
\hline & Frekuensi & Keyakinan & Dampak & Komunikasi & Total CAM \\
\hline Otonomi & 0,096 & 0,096 & $0,219^{*}$ & $-0,122$ & 0,135 \\
\hline Penguasaan & $0,221 *$ & 0,096 & $0,223^{*}$ & $-0,202 *$ & 0,178 \\
\hline lingkungan & & & & & \\
\hline $\begin{array}{l}\text { Pertumbuhan } \\
\text { pribadi }\end{array}$ & $0,284 * *$ & $0,253^{*}$ & $0,400^{* * *}$ & $-0,030$ & $0,350^{* * *}$ \\
\hline $\begin{array}{l}\text { Hubungan positif } \\
\text { dengan orang lain }\end{array}$ & $0,287 * *$ & $0,306^{* *}$ & $0,423 * *$ & $-0,132$ & $0,366^{* *}$ \\
\hline Tujuan hidup & $0,254 *$ & $0,302 * *$ & $0,391 * *$ & $-0,153$ & $0,318^{* *}$ \\
\hline Penerimaan diri & $0,384^{* *}$ & 0,460 ** & $0,481 * *$ & $-0,093$ & $0,491 * *$ \\
\hline Total PWB & $0,443 * *$ & $0,428 * *$ & 0,590 ** & $-0,152$ & $0,418^{* *}$ \\
\hline
\end{tabular}

**. Correlation is significant at the 0.01 level (2-tailed).

*. Correlation is significant at the 0.05 level (2-tailed).

\section{PEMBAHASAN}

Jenis terapi komplementer yang ditanyakan kepada responden sesuai klasifikasi National Center for Complementary and Alternative Medicine (NCCAM) yaitu 5 kategori sebagai berikut: terapi berbasis biologi, terapi pikiran-tubuh, manipulatif berbasis tubuh, terapi energi, dan sistem perawatan (Kramlich, 2014). Namun dalam penelitian ini yang digunakan oleh responden hanya 3 kategori yaitu terapi berbasis biologi, terapi pikiran-tubuh dan manipulatif berbasis tubuh, jenis yang terbanyak adalah pijat tradisional digunakan oleh responden untuk mengurangi keluhan pegal dan kelelahan, doa, air doa dan ruqiah digunakan untuk menjaga ketenangan hati. Penggunaan herbal yang banyak digunakan adalah jamu gendong ekstrak kunyit dan madu, Samadian et al (2017) meneliti tentang efek kunyit terhadap penurunan penanda inflamasi 
pada 71 pasien hemodialisis, hasil penelitian konsumsi kunyit terprogram tidak memiliki efek samping, adanya menurunkan kadar hsCRP, IL-6 dan TNF-a plasma yang disertai dengan peningkatan kadar albumin, tidak ada perubahan yang berarti pada nilai kalium dan fungsi hati sehingga kunyit dapat digunakan sebagai suplemen anti-inflamasi yang efektif pada pasien hemodialisis, penelitian keamanan kunyit dan madu pada pasien hemodialisis belum banyak dilakukan sehingga konsumsi terapi komplementer jenis herbal ini pada pasien PGK5D harus dalam pengawasan dan diketahui oleh dokter atau perawat di ruang hemodialisis.

Dalam penelitian ini dimensi penggunaan terapi komplementer yang masih rendah adalah keyakinan dan komunikasi yang dibangun antara pasien dengan petugas kesehatan tentang komplementer. Sikap negatif terhadap terapi komplementer atau pengalaman negatif dari menggunakan terapi komplementer, termasuk pengaruh petugas kesehatan dapat mempengaruhi pasien untuk tidak menggunakannya (Tangkiatkumjai, Boardman, Praditpornsilpa, \& Walker, 2014). Kesadaran tentang risiko interaksi terkait dengan terapi komplementer sangat rendah pada pasien dialisis (39\%) dan kesadaran meningkat ketika petugas kesehatan secara rutin mempertanyakan pasien tentang konsumsi terapi komplementer mereka (Nowack et al., 2009). Komunikasi antara petugas kesehatan dengan pasien PGK5D yang diteliti dalam penelitian ini hanya pada komunikasi tentang penggunaan jenis terapi komplementer dan tidak menanyakan hal-hal yang bersifat holistik meliputi tubuh pikiran dan jiwa, bagaimana emosi pasien, bagaimana persepsi pasien tentang penyakitnya, bagaimana semangat yang dibangun oleh pasien, hal itu merupakan keterbatasan dalam penelitian ini.

Adanya beberapa dimensi kesejahteraan psikologis yang rendah yaitu pada dimensi otonomi, tujuan hidup dan penerimaan diri juga dapat dipengaruhi oleh terapi komplementer yang telah diterima oleh pasien PGK5D, dalam penelitian ini peneliti tidak memberi batasan atau kriteria pada terapi komplementer yang digunakan oleh pasien dimana sebagian besar didapatkan pasien dari luar atau dari lingkungan masyarakat yang belum mendapatkan pendidikan dan pelatihan secara terstruktur sehingga terapi komplementer yang digunakan lebih kepada pengobatan tradisional komplementer yang didapat secara pengalaman dan turun temurun. Hal ini menjadi keterbatasan dalam penelitian ini dimana terapi komplementer adalah bagian dari keperawatan holistik yang telah didefinisikan sebagai upaya pengobatan yang bertujuan untuk menyembuhkan, dengan melibatkan hubungan antara aspek tubuh-pikiranjiwa dari setiap orang (Dossey, Keegan, \& Guzzetta, 2000). Ketika salah satu tidak dilakukan saat melakukan terapi komplementer maka hasil yang diharapkan mungkin akan mempengaruhi upaya penyembuhan pasien, terapi komplementer ini dapat menjadi salah satu modalitas intervensi yang dapat digunakan oleh perawat untuk meningkatkan psikologis pasien dengan menggunakan prinsip keperawatan holistik sehingga dapat membantu aspek dimensi penerimaan diri terutama bagi pasien yang telah menjalani hemodialisis lebih dari 1 tahun mereka dapat segera masuk kedalam tahap adaptasi jangka panjang. 
Pasien kurang mempunyai otonomi untuk memilih tidak dilakukan terapi pengganti meskipun petugas kesehatan memberikan pilihan bisa dengan hemodialisis atau peritoneal dialisis namun terapi ini merupakan terapi yang harus dilakukan untuk mempertahankan hidup dan dilakukan selama seumur hidup, ketergantungan pasien pada keluarga juga terlihat dalam penelitian ini hampir semua pasien diantar oleh keluarga hal ini memang bagus sebagai dukungan sosial namun disisi lain pasien akan sangat bergantung kepada keluarga dalam setiap pengambilan keputusan hal ini yang dapat menurunkan otonomi pasien PGK5D. Hasil penelitian ini sejalan dengan (Gerogianni \& Babatsikou, 2019), hemodialisis kronis dan jangka panjang menyebabkan perubahan dalam kehidupan pasien, sehingga sering menyebabkan hilangnya makna dalam kehidupan mereka dan peningkatan gangguan psikologis. Merasa tidak punya harapan dan citacita di masa depan dan hanya menjalani rutinitas hemodialisis setiap minggu membuat pasien memiliki nilai rata-rata yang rendah pada dimensi tujuan hidup.

Aspek penerimaan diri masih rendah karena dipengaruhi oleh karakteristik demografi responden dimana tingkat pendidikan dalam penelitian ini hanya sebagian kecil $7,2 \%$ responden berpendidikan tinggi dan sebagian besar berstatus tidak bekerja sebanyak 64,9\%, Menurut Ryff \& Keyes (1995) dalam Ruslanto (2018), pendidikan tinggi dan status pekerjaan dapat meningkatkan kesejahteraan psikologis, terutama pada dimensi penerimaan diri dan dimensi tujuan hidup. Orang dengan status sosial ekonomi yang tinggi mempunyai sikap dan perasaan yang lebih positif terhadap masa lalu dan penerimaan dirinya. Diperlukan dukungan dari petugas kesehatan untuk meningkatkan ketiga dimensi yang rendah yaitu otonomi, tujuan hidup dan penerimaan diri. Dukungan ini dapat berasal dari anak, suami dan isteri, keluarga, teman, rekan kerja, perawat, dokter, petugas kesehatan maupun organisasi sosial (Ryff \& Keyes (1995) dalam Ruslanto (2018).

Penggunaan terapi komplementer berpengaruh terhadap pengendalian tubuh. Perasaan, sikap dan emosi yang tenang menstimulasi tubuh mengeluarkan hormon yang memunculkan rasa tenang seperti endorphin. Hormon yang meningkatkan kecemasan dan emosi seperti adrenalin, nor adrenalin dan kortisol dihambat, sehingga terjadi keseimbangan dalam tubuh dan sistem organ tubuh akan berfungsi dengan baik (Artana, 2017). Penggunaan terapi komplementer dapat menstimulasi ketenangan sehingga pasien lebih dapat menjalani hidup yang bermakna dan mencapai kesejahteraan psikologis yang positif sehingga tujuan perawatan paliatif pada pasien PGK5D yang menjalani hemodialisis dapat tercapai dengan mengurangi gejala yang mengganggu, memperhatikan aspek psikologis dan spiritual pasien maupun keluarga serta untuk meningkatkan kualitas hidup.

Dalam penelitian ini responden menggunakan pijat tradisional yang dilakukan oleh tukang pijat tradisional yang berada di tengah masyarakat dimana sebagian besar bukan dari praktisi kesehatan, pijatan diberikan pada area tubuh yang dirasakan pegal seperti kaki, tangan, punggung, dimana pijat ini dilakukan sebagian besar dengan frekuensi 1 bulan sekali. Menurut Sitoresmi et al (2020) intervensi pijat terutama pada kaki 
merupakan salah satu intervensi yang dapat diberikan saat pasien melakukan hemodialisis. Pijat saat hemodialisis perlu dilakukan oleh perawat atau petugas kesehatan yang mempunyai keahlian dan kompetensi dibidangnya.

Efek dari jenis terapi komplementer yang digunakan responden dalam penelitian ini tidak dapat mengatasi kegagalan ginjal yang diderita pasien namun lebih kepada dapat meningkatkan persepsi pasien tentang well being yang dirasakan. Terapi komplementer yang berkembang ditengah masyarakat berakar pada budaya yang bertahun tahun telah digunakan oleh masyarakat dimana belum banyak penelitian tentang efek negatif terhadap kesehatan sehingga perawat perlu memilih strategi yang tepat dan melaksanakan tindakan yang sesuai dengan latar belakang budaya pasien yaitu mempertahankan budaya yang dimiliki pasien bila budaya tersebut tidak bertentangan dengan kesehatan seperti terapi doa yang digunakan oleh responden dapat dijadikan pilihan intervensi yang diberikan oleh perawat dengan memfasilitasi spiritual pasien seperti selama proses hemodialisis pasien diperdengarkan lantunan AlQuran dan doa yang disesuaikan dengan keyakinan pasien. Mengakomodasi atau negosiasi budaya pasien bila budaya tersebut kurang menguntungkan kesehatan seperti terapi air doa boleh diberikan ketika pasien hemodialisis tidak mengalami kelebihan cairan atau terapi pijat boleh diberikan kepada pasien PGK5D dengan memperhatikan keselamatan pasien dan merubah budaya pasien bila budaya yang dimiliki bertentangan dengan kesehatan seperti penggunaan beberapa herbal yang belum terbukti efek sampingnya terhadap fungsi ginjal (Giger, 2016).

\section{SIMPULAN}

Jenis terapi komplementer yang banyak digunakan pasien PGK5D dalam penelitian ini adalah teknik pijat tradisional, dengan dimensi penggunaan terapi komplementer yang memiliki nilai rendah ada pada dimensi keyakinan terhadap terapi komplementer dan komunikasi yang dibangun antara pasien dan petugas kesehatan tentang penggunaan terapi komplementer.

Psychological Well Being pada penelitian ini memiliki beberapa dimensi yang masih rendah seperti otonomi, tujuan hidup dan penerimaan diri. Adanya hubungan positif yang signifikan menunjukkan bahwa semakin tinggi penggunaan terapi komplementer maka semakin tinggi kesejahteraan psikologis pada pasien PGK5D yang menjalani hemodialisis di RSUD Sumedang dimana dimensi dampak penggunaan terapi komplementer memiliki hubungan yang paling tinggi dengan Psychological Well Being, pasien yang memiliki pengalaman positif tentang dampak terapi komplementer akan lebih dapat memanfaatkan peluang dari lingkungan sekitar dengan menggunakan salah satu atau beberapa jenis terapi komplementer untuk membantu mengatasi keluhan yang dirasakan yang akan meningkatkan kenyamanan dan kesejahteraan psikologis pasien.

Perawat perlu mendukung peningkatan kesejahteraan psikologis pasien PGK5D dengan pendekatan spiritual selama proses hemodialisis, perlu meningkatkan keahlian tentang terapi komplementer dan meningkatkan komunikasi selama intradialitik. 


\section{DAFTAR PUSTAKA}

Artana, I. W. (2017). Analisis fungsional terapi tradisional dan terapi komplementer alternatif di era jaminan kesehatan nasional (JKN). Caring Nursing Journal, 1, 53-61.

Bennett. (2015). The happiness and subjective well being of people on haemodialysis. Journal of Renal Care 41(3), 156-162.

Ceyhan \& Goris. (2017). The use of complementary and alternative medicine by patients undergoing hemodialysis. Alternative Therapies, Jan/Feb 2017 Vol. 23 No. 1, 23(1).

Chen ken Chih et al. (2010). Depression and suicide risk in hemodialysis patients with chronic renal failure. Psychosomatics, 51(6), 528528.e6.

https://doi.org/10.1016/S00333182(10)70747-7

Dossey, B. M., Keegan, L., \& Guzzetta, C. E. (2000). Holistic nursing a handbook for practice fourth edition.

Gerogianni \& Babatsikou. (2019). Chronic kidney disease and hemodialysis : epidemiological characteristics and psychological disorder. Perioperative Nursing, $8(2)$, 111-118. https://doi.org/10.5281/zenodo.3 491475

Giger, J. (2016). Transcultural nursing: Assessment and intervention, 7nd Ed. (M. year book Inc, Ed.).

Hasneli, Y. dan B. (2017). Hubungan lama menjalani hemodialisis dengan inter-dialytic weight gain (IDWG) pada pasien hemodialisis long-term relationship in hemodialysis with inter-dialytic weight gain (IDWG) on hemodialysis patients. Jurnal Keperawatan Universitas Padjajaran, 5(3), 242-248.

https://doi.org/10.24198/jkp.v5i3 .646

Indonesian Renal Registry. (2014). 7 th Report Of Indonesian Renal Registry 2014.

Kimmel, P. L. (2001). Psychosocial factors in dialysis patients. Kidney International, Vol. 59, 59, 1599-1613.

Kramlich, D. (2014). Introduction to complementary, alternative, and traditional therapies, 34(6), 5056.

NCCAM. (2008). The use of complementary and alternative medicine in the United States, (December).

Nowack, R., Birnkammer, F., Balle, C., Koch, W., Sessler, R., \& Birck, R. (2009). Complementary and alternative medications consumed by renal patients in Southern. Journal of Renal Nutrition, 19(3), 211-219. https://doi.org/10.1053/j.jrn.2008 .08 .008

Osman et al. (2015). Complementary and alternative medicine use. Journal of Renal Nutrition, 1-6. https://doi.org/10.1053/j.jrn.2015 .04 .009

Polit \& Beck. (2014). Nursing resesarch principles and methods. (lippincott williams \& wilkins, Ed.).

Ruslanto, J. (2018). Pengaruh job insecurity terhadap psychological well being. Universitas Padjadjaran.

Ryff, C. D. (2014). Psychological wellbeing revisited: Advances in the Science and practice of eudaimonia, 53706, 10-28. 
https://doi.org/10.1159/00035326 3

Samadian, F., Dalili, N., Gholi, F. P., Fattah, M., Malih, N., Nafar, M., ... Shadi, Z. (2017). Evaluation of curcumin's effect on inflammation in hemodialysis patients. Clinical Nutrition ESPEN, 2, 1-5. https://doi.org/10.1016/j.clnesp.2 017.09.006

Sitoresmi, H., Irwan, A. M., Sjattar, E. L., Fakultas, D., Keperawatan, I., Hasanuddin, U., \& Kunci, K. (2020). Intervensi keperawatan pada penderita gagal ginjal kronik yang menjalani hemodialisis : Sistematik review.
Jurnal Ilmiah Keperawatan.

Snyder \& Lindquist. (2018). Complementary and alternative therapies in nursing (Eight Edit). New York: Springer.

Tangkiatkumjai, M., Boardman, H., Praditpornsilpa, K., \& Walker, D. (2014). Reasons why Thai patients with CKD use or do not use herbal and dietary supplements. BMC Complementary and Alternative Medicine, 1-9.

Widyatuti. (2008). Terapi komplementer dalam keperawatan. Jurnal Keperawatan Indonesia, 12, No $1, \quad 53-57$. 